\title{
Properties of Glued Laminated Timber Made from Fast-growing Species with Mangium Tannin and Phenol Resorcinol Formaldehyde Adhesives ${ }^{1}$
}

\author{
Jessica Hendrik ${ }^{2}$ Yusuf Sudo Hadi (D) ${ }^{2, \dagger}$ - Muh Yusram Massijaya ${ }^{2}$ • \\ Adi Santoso ${ }^{3} \cdot$ Antonio Pizzi $^{4}$
}

\begin{abstract}
This study characterized the chemical compounds in tannin from mangium (Acacia mangium) bark extract and determined the physical-mechanical properties of glued laminated timber (glulam) made from sengon (Falcataria moluccana), jabon (Anthocephalus cadamba), and mangium wood. The adhesives used to prepare the glulam were based on mangium tannin and phenol resorcinol formaldehyde resin. Five-layer glulam beams measuring $5 \mathrm{~cm} \times 6 \mathrm{~cm} \times$ $120 \mathrm{~cm}$ in thickness, width, and length, respectively, were made with a glue spread of $280 \mathrm{~g} / \mathrm{m}^{2}$ for each glue line, cold pressing at $10.5 \mathrm{kgf} / \mathrm{cm}^{2}$ for $4 \mathrm{~h}$ and clamping for $20 \mathrm{~h}$. Condensed mangium tannin consisted of $49.08 \%$ phenolic compounds with an average molecular weight of 4745 . The degree of crystallinity was $14.8 \%$. The Stiasny number was $47.22 \%$. The density and the moisture content of the glulams differed from those of the corresponding solid woods with mangium having the lowest moisture content $(9.58 \%)$ and the highest density $\left(0.66 \mathrm{~g} / \mathrm{cm}^{3}\right)$. The modulus of rupture for all glulam beams met the JAS 234-2003 standard but the modulus of elasticity and the shear strength values did not. Glulam beams made with tannin had high delamination under dry and wet conditions, but glulam made from sengon and jabon wood met the standard's requirements. All glulam beams had low formaldehyde emissions and were classified as $\mathrm{F}^{* * * *}$ for formaldehyde emissions according to the JAS 234 (2003) standard.
\end{abstract}

Keywords: tannin resorcinol formaldehyde adhesive, phenol resorcinol formaldehyde adhesive, glued laminated lumber (glulam), fast-growing species

\section{INTRODUCTION}

Mangium (Acacia mangium), which produces short-fibered wood, has come to dominate plantations in Indonesia because of the high demand for pulp and paper, which reached 410 million tons in 2017 (Hermes, 2018). Mangium bark is consequently an abundant waste byproduct in the Indonesia wood industries, particularly in the pulp and paper industry, and it is often used as firewood or as fuel for industry. Mangium bark contains a high level of tannin, composed of naturally occurring polyphenolic compounds that are soluble in water (Hoong et al., 2011). These compounds can be used in various applications, including the

\footnotetext{
${ }^{1}$ Date Received August 3, 2018, Date Accepted April 16, 2019

2 Department of Forest Products, Forestry Faculty, Bogor Agricultural University, Bogor 16680, Indonesia

${ }^{3}$ Forest Products Research Institute, Bogor 16680, Indonesia

${ }^{4}$ ENSTIB-LERMAB,University of Lorraine, Epinal, France

† Corresponding author: Yusuf Sudo Hadi (e-mail: yshadi@indo.net.id, ORCID: 0000-0002-2212-4501)
} 
manufacture of wood adhesives.

Santoso et al. (2016) reported that merbau (Instia spp.) wood extracts contained flavonoid oligomers with up to six repeating units, and the extracts could be used in adhesives for glulam manufacturing, especially with medium-density woods. At present, the commercial and industrial tannin extracts usable in wood adhesives are mainly obtained from the bark of mimosa (Acacia mearnsii), quebracho (Schinopsis balansae), and pines, including Pinus merkusii (Fradinho et al., 2002; Panamgama, 2007; Vazquez et al., 2000) and Pinus radiata barks (Valenzuela et al., 2012). Previous research demonstrated that condensed tannin extracts can be successfully used as substitutes for phenol in the production of phenol-formaldehyde resins, resorcinol-formaldehyde resins, and phenol-resorcinol -formaldehyde (PRF) resins and that condensed tanninformaldehyde wood adhesives can be used for interior and exterior wood bonding of products such as particleboard and plywood (Pizzi, 1983). These naturally occurring polyphenolic compounds can also be used as a raw material for adhesives in manufacturing of glued laminated timber (glulam) (Lestari et al., 2015) and laminated board (Hendrik et al., 2016).

Indonesian plantation forests are dominated by fast-growing tree species such as jabon (Anthocephalus cadamba), sengon (Falcataria moluccana), and mangium. These species have cutting cycles of 5-10 years, and a diameter of less than $30 \mathrm{~cm}$, and their quality is inferior compared to logs from natural forests (Hadi et al., 2015). Glulam is one option for improving the quality of wood and its physical and mechanical properties, with no restriction on its dimensions. The objectives of the current study were to characterize mangium wood extract and to determine the physical and mechanical properties of glulams made from three fast-growing wood species and adhesive based on either tannin from the mangium extract or PRF. The physical and mechanical properties, shear strength, and delami- nation of the glulams were evaluated, and the results were compared to the Japanese Agricultural Standard (JAS) 234 (2003) for glued laminated timber.

\section{MATERIALS and METHODS}

Chipped mangium stem bark was oven-dried and underwent hot-water extraction $\left(70{ }^{\circ} \mathrm{C}-80{ }^{\circ} \mathrm{C}\right)$, and the resultant liquid extract was then filtered. The filtered extract then underwent spray drying, which produced tannin powder. Tannin yield was calculated from the difference between the weight of the tannin powder and the weight of the oven-dried bark prior to extraction. The Stiasny number method, as described by Yazaki and Collins (1997), was used to determine reactivity of the polyphenol with formaldehyde. A total of 0.12 $\mathrm{g}$ of the tannin powder was added to a $150-\mathrm{mL}$ flask containing $10 \mathrm{~mL}$ of water. Aqueous formaldehyde (37 $\%$; $2 \mathrm{~mL}$ ) and hydrochloric acid (10 N; $1 \mathrm{~mL}$ ) were added to the solution, and the mixture was then heated to $100{ }^{\circ} \mathrm{C}$ for $30 \mathrm{~min}$. The reaction mixture was filtered while it was still hot, and the precipitate was dried in an oven at $105{ }^{\circ} \mathrm{C}$ to constant weight. The Stiasny number was determined according to the following equation:

Stiasny precipitation number

$=\frac{\text { Oven }- \text { dried weight of the precipitate }}{\text { Total dissolved solids content }} \times 100 \%$

The tannin powder was analyzed by matrix-assisted laser desorption/ionization-time of flight (MALDITOF; Shimadzu Biotech Axima Performance 2.9.3. 20110624), x-ray diffraction (XRD, Shimadzu, Kyoto, Japan), and by pyrolysis gas chromatography-mass spectrometry (GCMS; Py-GCMS-QPXP-2010, Shimadzu, Japan). Mangium tannin adhesive was made by mixing tannin powder and mangium extract liquid $(1: 4 \mathrm{~m} / \mathrm{m})$ to produce a tannin solution. Next, $9 \mathrm{~g}$ of resorcinol, $10 \mathrm{~mL}$ of formaldehyde, and $10 \mathrm{~mL}$ of sodium hydroxide 
$40 \%$ were added for each $100 \mathrm{~mL}$ of the tannin solution. The mixture was stirred at room temperature for approximately $15 \mathrm{~min}$.

Glulam was made with wood from 5- to 7-year-old trees of three species, sengon, jabon, and mangium. The trees were harvested from Bogor, West Java, Indonesia. The lumber was processed into lamina sheets that were $1 \mathrm{~cm} \times 6 \mathrm{~cm} \times 120 \mathrm{~cm}$ in thickness, width, and length, respectively. The laminas were air dried and then kiln-dried to a moisture content of approximately $12 \%$. Lamina sorting was performed by modulus of elasticity (MOE) prediction using a nondestructive device (Panther version MPK-5, IPB, Bogor, Indonesia) for quality sorting. Laminas used for the face and back layers of glulam had higher MOE values than the core laminas. Each lamina was bonded using either mangium tannin adhesive, which had a solids content of $24.02 \%$ and a viscosity of $95 \mathrm{cP}$, or PRF, a polymer consisting of a base resin and hardener. Glue was double spread at $280 \mathrm{~g} / \mathrm{m}^{2}$, and the laminas were then pressed using a cold press machine at a pressure of $12 \mathrm{MPa}$ for $4 \mathrm{~h}$ and then clamped for $20 \mathrm{~h}$. The resultant five-layer homogeneous glulam measured 5 $\mathrm{cm} \times 6 \mathrm{~cm} \times 120 \mathrm{~cm}$ in thickness, width, and length, respectively. The glulam was cut to various sizes for different tests as shown in Fig. 1. For comparison purposes, solid wood representing a material without adhesive was used for control samples. The solid wood samples were the same size as the glulam samples. Five test specimens were used for each treatment.

The physical and mechanical properties of glulam were tested according to the standard for glued laminated timber (JAS 234-2003 (2003)). Physical properties were tested based on the moisture content, density, and width shrinkage, and mechanical properties were tested with a Universal Testing Machine (Universal Testing Machine, Shimadzu Corporation, Kyoto, Japan) to determine the modulus of rupture (MOR), MOE, and shear strength. For MOR and MOE tests, one-point

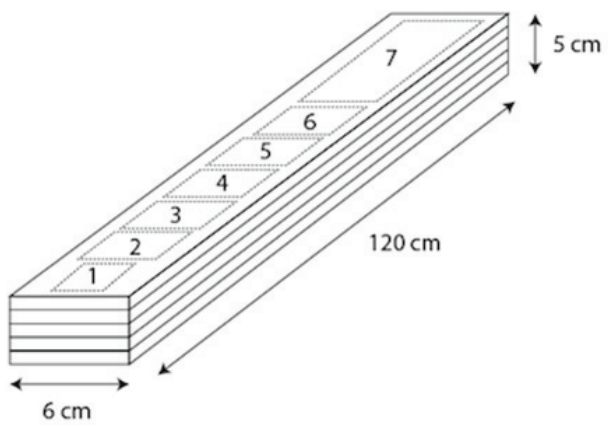

Sample testing for formaldehyde emission

$(2.5 \mathrm{~cm} \times 5 \mathrm{~cm} \times 5 \mathrm{~cm})$

Sample testing for shear strength

$(5 \mathrm{~cm} \times 5 \mathrm{~cm} \times 5 \mathrm{~cm})$

Sample testing for density

$(5 \mathrm{~cm} \times 5 \mathrm{~cm} \times 5 \mathrm{~cm})$

Sample testing for moisture content

$(5 \mathrm{~cm} \times 5 \mathrm{~cm} \times 5 \mathrm{~cm})$

Sample testing for delamination (in hot water)

$(5 \mathrm{~cm} \times 5 \mathrm{~cm} \times 5 \mathrm{~cm})$

Sample testing for delamination (in cold water)

$(5 \mathrm{~cm} \times 5 \mathrm{~cm} \times 5 \mathrm{~cm})$

Sample testing for MOR and MOE

$(5 \mathrm{~cm} \times 75 \mathrm{~cm} \times 5 \mathrm{~cm})$

Fig. 1. Cutting model of glulam for each test specimen.

loading was applied with a span of $70 \mathrm{~cm}$ and a load speed of $3 \mathrm{~mm} / \mathrm{min}$.

Hot water delamination tests were done by boiling each test specimen in water $\left(100{ }^{\circ} \mathrm{C}\right)$ for $4 \mathrm{~h}$, soaking it in water at room temperature for $1 \mathrm{~h}$, and then placing it in an oven at $70 \pm 3{ }^{\circ} \mathrm{C}$ for $18 \mathrm{~h}$. The cold water delamination test was carried out by soaking test specimens in water at room temperature for $6 \mathrm{~h}$ and then putting them in the oven at a temperature of 40 $\pm 3^{\circ} \mathrm{C}$ for $18 \mathrm{~h}$. The delamination ratio was calculated using Eq. 2.

Delamination ratio (\%)

$=\frac{\text { Sum of delaminated lengths of two cross sections }}{\text { Sum of gluing lengths of two cross sections }} \times 100 \% \quad \cdots$

To test formaldehyde emissions, samples sized 2.5 $\mathrm{cm} \times 2.5 \mathrm{~cm} \times 5 \mathrm{~cm}$ were hung in bottles containing $25 \mathrm{~mL}$ of distilled water without coming into contact 
with the water. The bottles containing the samples were placed in an oven at $40 \pm 2{ }^{\circ} \mathrm{C}$ for $24 \mathrm{~h}$. Ten milliliters of water from each bottle was mixed with $10 \mathrm{~mL}$ of acetyl ammonium acetate reagent and the absorbance of the solution was measured with a spectrophotometer at $\lambda=412 \mathrm{~nm}$ to determine the formaldehyde concentration.

Data analysis was undertaken using a factorial design. The first factor was wood species (i.e., sengon, jabon, and mangium), and the second factor was the type of adhesive (i.e., solid or nonadhesive, tannin adhesive, and PRF). If the analysis of variance indicated that any treatment was significantly different $(P \leq 0.05)$, Duncan's multi-range test was used for further analysis.

\section{RESULTS and DISCUSSION}

\subsection{Chemical analysis of mangium tannin extract}

The Stiasny number indicates the reactivity of tannin with formaldehyde. The reactivity can be affected by the bark freshness, source of wood, tree habitat, and extraction method (Achmadi, 1990). Tannin extract accounted for $377.6 \mathrm{~g}$ of the $3 \mathrm{~kg}$ of mangium bark (12.59\% by weight) that underwent extraction, and it had a Stiasny number of $47.22 \%(\mathrm{w} / \mathrm{w})$.

The pyrolysis GCMS chromatograph (Fig. 2) indicated that the mangium tannin extract contained phenol,

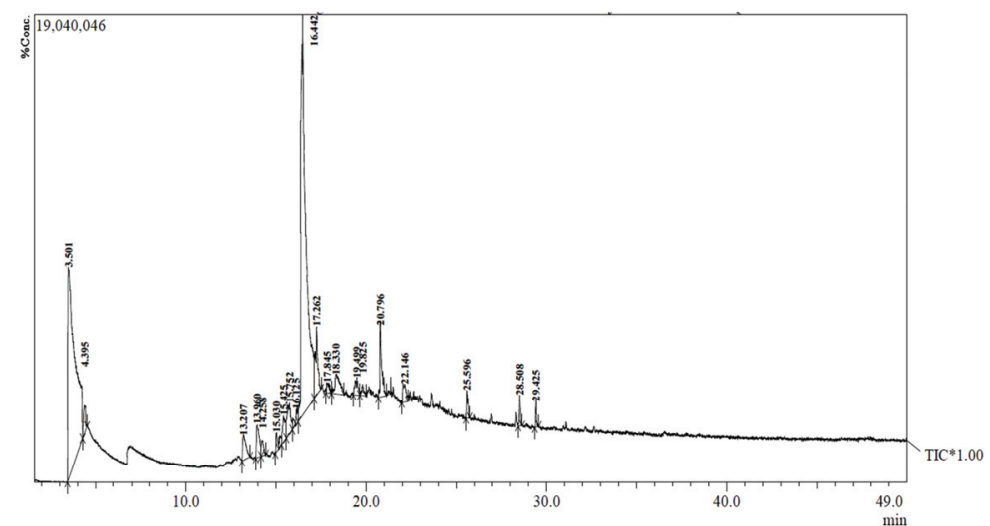

(a)

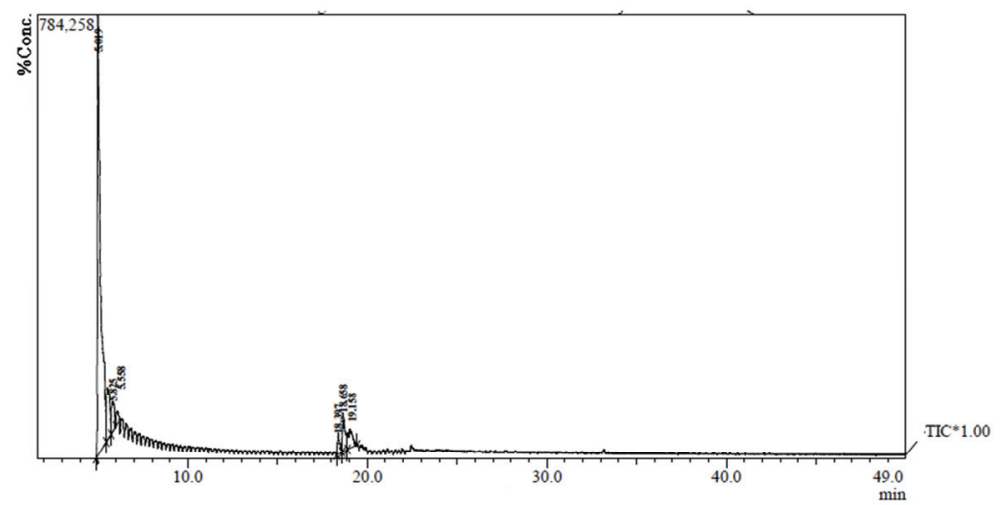

(b)

Fig. 2. Chromatograph of mangium tannin extract (a) and tannin resorcinol formaldehyde, TRF (b). 
Properties of Glued Laminated Timber Made from Fast-growing Species with Mangium Tannin and Phenol Resorcinol Formaldehyde Adhesives

Table 1. Chromatic photometric absorption bands of mangium tannin extract and TRF

\begin{tabular}{|c|c|c|c|c|}
\hline \multirow{2}{*}{ Compound } & \multicolumn{2}{|c|}{ Mangium tannin extract } & \multicolumn{2}{|c|}{ TRF } \\
\hline & Retention time (min) & Concentration (\%) & Retention time (min) & Concentration (\%) \\
\hline Phenol (izal) & 13.2 & 1.83 & & \\
\hline 2-Methoxyphenol, (guaiacol) & 13.96 & 2.18 & & \\
\hline 4-Methylphenol, ( $p$-cresol) & 14.25 & 0.74 & & \\
\hline 4-Ethenyl-2-methoxyphenol & 16.12 & 0.91 & & \\
\hline 1,3-Benzenediol (pyrocatechol) & 16.14 & 42.83 & & \\
\hline $\begin{array}{l}\text { 4-Ethyl-1,3-benzenediol } \\
\text { (4-ethylresorcinol) }\end{array}$ & 17.84 & 0.59 & & \\
\hline Trideuteroacetonitrile & & & 5.2 & 78.46 \\
\hline Nitrogen oxide & & & 5.6 & 8.94 \\
\hline 2-Methylene-7-oxabicyclo & & & 18.39 & 2.53 \\
\hline 2-Methoxy-4-methylphenol & & & 19.16 & 10.07 \\
\hline Total phenolic compounds & & 49.08 & & 10.07 \\
\hline
\end{tabular}

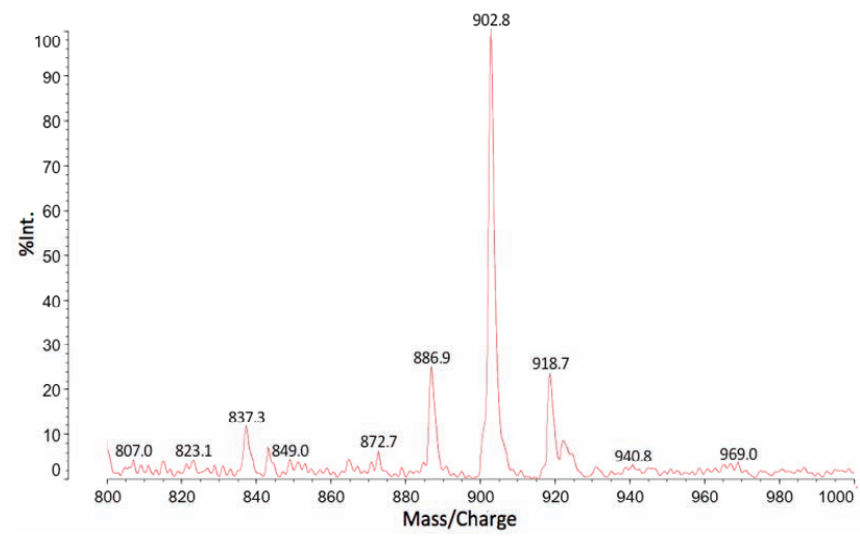

(a)

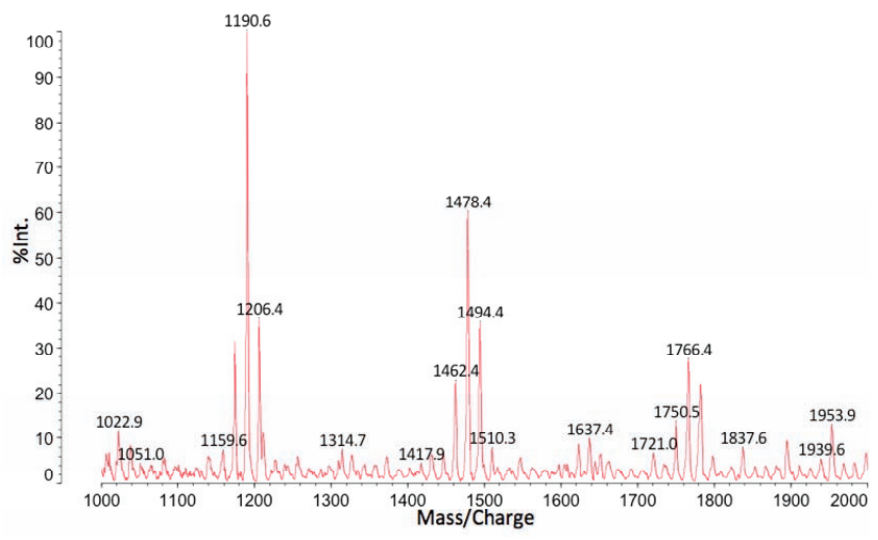

(b)

Fig. 3. MALDI mass spectrum of (a) details of the 800-1000 Da range; (b) details of the 1000-2000 Da range. 
Table 2. MALDI peaks for the mangium tannin extract

\begin{tabular}{|c|c|c|c|c|}
\hline \multirow{2}{*}{$\begin{array}{c}\mathrm{M}+\mathrm{Na}+ \\
\text { Experimental }\end{array}$} & \multirow{2}{*}{$\begin{array}{l}\mathrm{M}+\mathrm{Na}+ \\
\text { Calculated }\end{array}$} & \multicolumn{3}{|c|}{ Unit type } \\
\hline & & A & B & $\mathrm{C}$ \\
\hline \multicolumn{5}{|l|}{ "Monomer } \\
\hline 272.3 & 272.3 & 1 & - & - \\
\hline 303.3 & 304.3 & - & - & 1 \\
\hline \multicolumn{5}{|l|}{ Dimers } \\
\hline 603.4 & 601.6 & - & 2 & - \\
\hline 615.3 & 617.6 & - & 1 & 1 \\
\hline \multicolumn{5}{|l|}{ Trimers } \\
\hline 872.7 & 873.9 & 1 & 2 & - \\
\hline 886.9 & 889.9 & - & 3 & - \\
\hline 902.8 & 905.9 & - & 2 & 1 \\
\hline 918.7 & 921.9 & - & 1 & 2 \\
\hline \multicolumn{5}{|l|}{ Tetramers } \\
\hline 1159.6 & 1162.2 & 1 & 3 & - \\
\hline 1174 & 1178.2 & - & 4 & - \\
\hline 1190.6 & 1194.2 & - & 3 & 1 \\
\hline 1206.4 & 1210.2 & - & 2 & 2 \\
\hline \multicolumn{5}{|l|}{ Pentamers } \\
\hline 1462.4 & 1466.5 & 1 & 3 & 1 \\
\hline 1478.4 & 1482.5 & - & 4 & 1 \\
\hline 1494.4 & 1498.5 & - & 3 & 2 \\
\hline 1510.3 & 1514.5 & - & 2 & 3 \\
\hline \multicolumn{5}{|l|}{ Hexamers } \\
\hline 1750.5 & 1754.8 & 1 & 4 & 1 \\
\hline 1766.4 & 1770.8 & - & 5 & 1 \\
\hline 1782 & 1786.8 & - & 4 & 2 \\
\hline \multicolumn{5}{|l|}{ Heptamers } \\
\hline 2070.4 & 2075.1 & - & 5 & 2 \\
\hline
\end{tabular}

and its molecular weight was $866 \mathrm{~g} / \mathrm{mol}$, which was much lower than previously reported values for tannin from pine (3200 g/mol) and mimosa (1250 g/mol) (von
Leyser and Pizzi, 1990). The pyrolysis GCMS showed that the mangium tannin extract was dominated by hydroxyl groups, aromatic groups, and ether groups. Pyrolysis GCMS revealed that the phenolic compounds accounted for $49.08 \%(\mathrm{w} / \mathrm{w})$ of the extract and were dominated by 1,3-benzenediol, similar to the results of Santoso et al. (2016), who found that liquid extract of merbau wood was dominated by 1,3-benzenediol.

The pyrolysis GCMS chromatograph (Fig. 2a) indicated that the mangium tannin contained phenol and many other peaks. Therefore, in Table 1 the total phenolic content was decreased in tannin resorcinol formaldehyde (TRF), due to reaction between mangium tannin and resorcinol formaldehyde forming a new chemical component. Based on the retention times obtained, mangium tannin appeared to be able to react with resorcinol and formaldehyde.

Fig. 3 shows a representative MALDI-TOF spectrum of mangium tannin, with a molecular weight ranging from 30 to $2000 \mathrm{Da}$. The molecular weight of the predominant repeating unit was $272 \mathrm{Da}$, indicating that this tannin was a profisetinidin. The MALDI peaks indicated the presence of oligomers in the tannin, with the largest being heptamers (2075 Da), and the distribution is shown in Table 2. The flavonoid repeating units present in this tannin extract were types $\mathrm{A}$ for recorsinol-katekol (274 Da), B for recorsinol-pyrogallol (290 Da), and C for floroglusinoll-pyrogallol (306 Da) (Fig. 4). Table 2 shows that many valid combinations of different repeating units are possible.

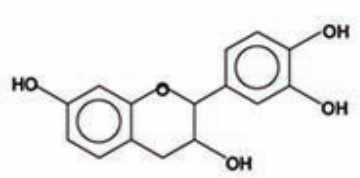

A

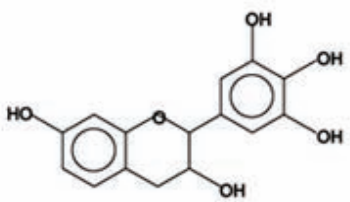

B

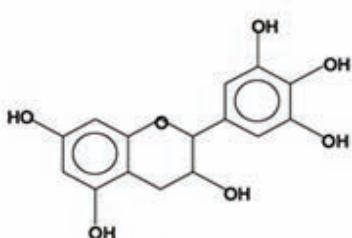

C

Fig. 4. The flavonoid units in mangium tannin extract. 
Properties of Glued Laminated Timber Made from Fast-growing Species with Mangium Tannin and Phenol Resorcinol Formaldehyde Adhesives

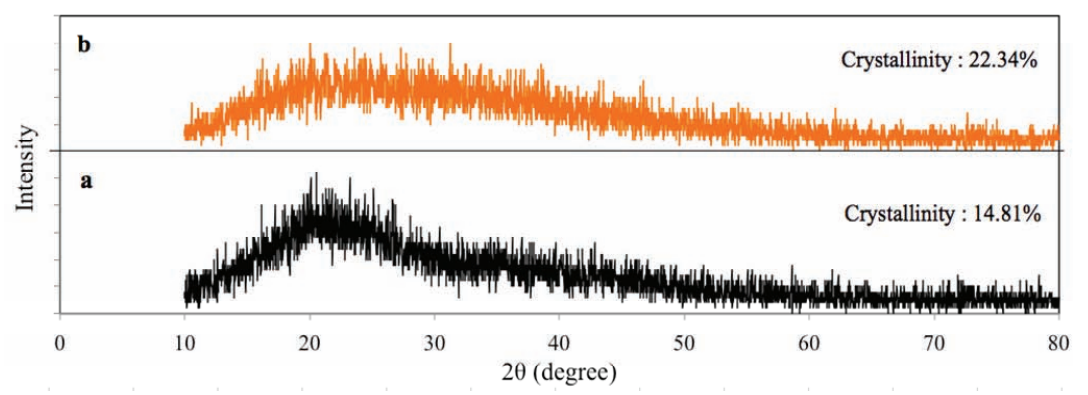

Fig. 5. X-ray diffraction patterns of mangium extract (a) and TRF (b).

Table 3. Physical properties of glulams

\begin{tabular}{cccc}
\hline \multirow{2}{*}{ Wood species } & Adhesive & \multicolumn{2}{c}{ Physical } \\
\cline { 2 - 4 } & & Density $\left(\mathrm{g} / \mathrm{cm}^{3}\right)$ & Moisture content $(\%)$ \\
\hline \hline \multirow{2}{*}{ Sengon } & Solid & $0.35 \pm 0.01$ & $10.54 \pm 0.62$ \\
\cline { 2 - 4 } & TRF & $0.31 \pm 0.03$ & $14.68 \pm 0.21$ \\
\cline { 2 - 4 } & PRF & $0.34 \pm 0.03$ & $14.06 \pm 0.51$ \\
\cline { 2 - 4 } & Solid & $0.33 \pm 0.01$ & $10.74 \pm 0.16$ \\
\cline { 2 - 4 } & TRF & $0.33 \pm 0.01$ & $14.57 \pm 0.62$ \\
\hline Mabon & PRF & $0.35 \pm 0.01$ & $14.63 \pm 0.11$ \\
\cline { 2 - 4 } & Solid & $0.61 \pm 0.01$ & $11.63 \pm 0.72$ \\
\cline { 2 - 4 } & TRF & $0.70 \pm 0.02$ & $9.19 \pm 0.70$ \\
\hline JAS standard & PRF & $0.67 \pm 0.04$ & Max 15 \\
\hline
\end{tabular}

Copolymerization reactions may lead to changes in the molecular and crystalline structure of the mangium tannin, and an understanding of its molecular and crystalline structures and the changes would provide valuable information regarding bonding performance. The XRD patterns of mangium extract and TRF adhesive are shown in Fig. 5 the $y$-axis represents the intensity. The results indicate that the degree of crystallinity of the mangium tannin powder increased from $14.8 \%$ to $22.34 \%$ when it copolymerized with resorcinol and formaldehyde.

\subsection{Physical properties of glulam}

The physical properties of glulam and solid wood are shown in Table 3. Glulam and mangium solid wood had higher densities $\left(0.66 \pm 0.02 \mathrm{~g} / \mathrm{cm}^{3}\right)$ than glulam and jabon solid wood $\left(0.34 \pm 0.01 \mathrm{~g} / \mathrm{cm}^{3}\right)$ and sengon wood $\left(0.33 \pm 0.02 \mathrm{~g} / \mathrm{cm}^{3}\right)$. The analysis of variance showed that sengon, jabon, and mangium woods had significantly different densities (Table 4). However, the type of adhesive did not significantly affect the density, and the three types of product (solid wood, glulam bonded by TRF, and glulam bonded by PRF) had the same density values.

Table 3 shows that the moisture content of the sengon

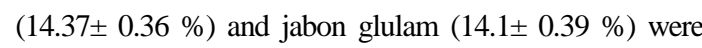
higher than mangium glulam $8.55 \pm 0.80 \%$. The moisture content fulfilled the JAS 234 (2003) standard, which sets the allowable moisture content at less than $15 \%$. According to the analysis of variance shown in Table 4, the moisture content of glulam was affected by the wood species, the type of adhesive, and the 
Table 4. ANOVA of physical and mechanical properties of glulam

\begin{tabular}{lccc}
\hline Parameter & Wood species (A) & Adhesive (B) & Interactions (AB) \\
\hline \hline Density $\left(\mathrm{g} / \mathrm{cm}^{3}\right)$ & $* *(0.00)$ & NS $(0.09)$ & $*(0.00)$ \\
Moisture content $(\%)$ & $* *(0.00)$ & $* *(0.00)$ & $* *(0.00)$ \\
MOE $\left(\mathrm{kgf} / \mathrm{cm}^{2}\right)$ & $* *(0.00)$ & NS $(0.40)$ & $*(0.01)$ \\
MOR $\left(\mathrm{kgf} / \mathrm{cm}^{2}\right)$ & $* *(0.00)$ & $* *(0.00)$ & $* *(0.00)$ \\
Shear strength DC $\left(\mathrm{kgf} / \mathrm{cm}^{2}\right)$ & $* *(0.00)$ & $* *(0.00)$ & $*(0.014)$ \\
Shear strength WC $\left(\mathrm{kgf} / \mathrm{cm}^{2}\right)$ & $* *(0.00)$ & $* *(0.00)$ & $*(0.023)$ \\
Delamination in cold water & $*(0.015)$ & $*(0.027)$ & $*(0.025)$ \\
Delamination in hot water & $* *(0.00)$ & $* *(0.00)$ & $*(0.00)$ \\
\hline
\end{tabular}

**Very significant $(\mathrm{P} \leq 0.01)$; *Significant $(\mathrm{P} \leq 0.05)$; NS = not significant.

Table 5. Duncan's test for the physical and mechanical properties of glulam based on wood species

\begin{tabular}{|c|c|c|c|c|c|c|c|c|}
\hline $\begin{array}{l}\text { Wood } \\
\text { species }\end{array}$ & $\begin{array}{l}\text { Density } \\
\left(\mathrm{g} / \mathrm{cm}^{3}\right)\end{array}$ & MC (\%) & $\begin{array}{c}\mathrm{MOE} \\
\left(\mathrm{kgf} / \mathrm{cm}^{2}\right)\end{array}$ & $\begin{array}{c}\text { MOR } \\
\left(\mathrm{kgf} / \mathrm{cm}^{2}\right)\end{array}$ & $\begin{array}{l}\text { Shear } \\
\text { strength dry } \\
\text { cond. } \\
\left(\mathrm{kgf} / \mathrm{cm}^{2}\right)\end{array}$ & $\begin{array}{c}\text { Shear } \\
\text { strength wet } \\
\text { cond. } \\
\left(\mathrm{kgf} / \mathrm{cm}^{2}\right)\end{array}$ & $\begin{array}{c}\text { Delamination } \\
\text { in cold } \\
\text { water }(\%)\end{array}$ & $\begin{array}{c}\text { Delamination } \\
\text { in hot water } \\
(\%)\end{array}$ \\
\hline Sengon & $0.33 a$ & $13.09 a$ & $44,382 \mathrm{a}$ & $368 a$ & $28.14 a$ & $14.02 \mathrm{a}$ & $1.00 \mathrm{a}$ & $0.00 \mathrm{a}$ \\
\hline Jabon & $0.34 \mathrm{a}$ & 13.31a & $46,891 \mathrm{a}$ & $388 a$ & $44.52 b$ & $16.02 \mathrm{a}$ & $0.00 \mathrm{a}$ & $0.60 \mathrm{a}$ \\
\hline Mangium & $0.66 \mathrm{~b}$ & $9.58 b$ & $104,276 b$ & $584 \mathrm{~b}$ & $40.77 b$ & $33.62 b$ & $12.30 \mathrm{~b}$ & $35.30 \mathrm{~b}$ \\
\hline
\end{tabular}

Remarks: Values followed by the same letters within a column are not significantly different. MC, moisture content.

interaction between wood species and type of adhesive. Based on Duncan's multi range test sengon and jabon were not different from one another (Table 5), but the glulam was different from the solid wood (Table 6).

\subsection{Mechanical properties of glulam}

The MOE values of solid wood and glulam are shown in Table 7. Only mangium glulams $(107,318 \pm 4,674$ $\mathrm{kgf} / \mathrm{cm}^{2}$ ) met the standard JAS 234 (2003), which sets the allowable MOE at more than $75,000 \mathrm{kgf} / \mathrm{cm}^{2}$. The MOE values of glulam made from sengon and jabon wood bonded by tannin adhesive and PRF were lower than those of solid wood. Compare the glulam from jabon wood glued with TRF $\left(47,114 \mathrm{kgf} / \mathrm{cm}^{2}\right)$ had a lower value than glulam 3-layers glued with isocyanate
(56,084 kgf/ $/ \mathrm{cm}^{2}$ ) (Lestari et al., 2018). According to the analysis of variance shown in Table 4, the MOE of glulam was not affected by the type of adhesive, but it was affected by wood species and the interaction between wood species and type of adhesive.

The MOR values for glulam and solid wood are shown in Table 7. All samples made with TRF adhesive had lower MOR values than those made with PRF and the solid wood. However, all glulams had an MOR that met JAS 234 (2003), which sets the allowable MOR at more than $300 \mathrm{kgf} / \mathrm{cm}^{2}$. Compared to larix glulam which was manufactured with resorcinol formaldehyde adhesive using glue spread $300 \mathrm{~g} / \mathrm{m}^{2}$ reaching MOR $392 \mathrm{kgf} / \mathrm{cm}^{2}$ (Lee and Hong, 2016), the MOR of mangium glulam using TRF was $379 \mathrm{kgf} / \mathrm{cm}^{2}$ or a little bit lower of larix glulam, but if using PRF the MOR 
Properties of Glued Laminated Timber Made from Fast-growing Species with Mangium Tannin and Phenol Resorcinol Formaldehyde Adhesives

Table 6. Duncan's test for the physical and mechanical properties of glulam based on adhesive type

\begin{tabular}{lllccc}
\hline $\begin{array}{l}\text { Bonding } \\
\text { system }\end{array}$ & $\begin{array}{l}\text { Density } \\
\left(\mathrm{g} / \mathrm{cm}^{3}\right)\end{array}$ & $\begin{array}{l}\text { MC } \\
(\%)\end{array}$ & $\begin{array}{c}\text { MOE } \\
\left(\mathrm{kgf} / \mathrm{cm}^{2}\right)\end{array}$ & $\begin{array}{c}\text { MOR } \\
\left(\mathrm{kgf} / \mathrm{cm}^{2}\right)\end{array}$ & $\begin{array}{c}\text { Shear strength DC } \\
\left(\mathrm{kgf} / \mathrm{cm}^{2}\right)\end{array}$ \\
\hline \hline Solid wood & $0.43 \mathrm{a}$ & $10.97 \mathrm{a}$ & $65,999 \mathrm{a}$ & $512 \mathrm{a}$ & $54.45 \mathrm{a}$ \\
TRF & $0.44 \mathrm{ab}$ & $12.81 \mathrm{~b}$ & $63,034 \mathrm{a}$ & $349 \mathrm{~b}$ & $25.56 \mathrm{~b}$ \\
PRF & $0.45 \mathrm{~b}$ & $12.20 \mathrm{~b}$ & $66,516 \mathrm{a}$ & $478 \mathrm{a}$ & $33.42 \mathrm{c}$ \\
\hline
\end{tabular}

Table 7. Mechanical properties of glulams

\begin{tabular}{|c|c|c|c|c|c|}
\hline \multirow[b]{2}{*}{ Wood species } & \multirow[b]{2}{*}{ Adhesive } & \multicolumn{4}{|c|}{ Mechanical } \\
\hline & & $\begin{array}{c}\mathrm{MOE} \\
\left(\mathrm{kgf} / \mathrm{cm}^{2}\right)\end{array}$ & $\begin{array}{c}\mathrm{MOR} \\
\left(\mathrm{kgf} / \mathrm{cm}^{2}\right)\end{array}$ & $\begin{array}{l}\text { Shear strength dry cond. } \\
\left(\mathrm{kgf} / \mathrm{cm}^{2}\right)\end{array}$ & $\begin{array}{l}\text { Shear strength wet cond. } \\
\left(\mathrm{kgf} / \mathrm{cm}^{2}\right)\end{array}$ \\
\hline \multirow[t]{3}{*}{ Sengon } & Solid & $51,499 \pm 2248$ & $457 \pm 15$ & $40.82 \pm 2.89$ & - \\
\hline & TRF & $37,999 \pm 2000$ & $319 \pm 51$ & $22.19 \pm 2.08$ & $19.23 \pm 3.71$ \\
\hline & PRF & $43,647 \pm 3290$ & $327 \pm 48$ & $21.43 \pm 5.61$ & $8.81 \pm 2.29$ \\
\hline \multirow[t]{3}{*}{ Jabon } & Solid & $48,304 \pm 3218$ & $428 \pm 20$ & $59.31 \pm 4.62$ & - \\
\hline & TRF & $47,114 \pm 3427$ & $351 \pm 35$ & $32.36 \pm 6.54$ & $16.64 \pm 2.40$ \\
\hline & PRF & $45,256 \pm 3442$ & $383 \pm 23$ & $41.88 \pm 12.54$ & $15.40 \pm 3.31$ \\
\hline \multirow[t]{3}{*}{ Mangium } & Solid & $98,193 \pm 3672$ & $650 \pm 23$ & $63.21 \pm 2.51$ & - \\
\hline & TRF & $103,990 \pm 15,079$ & $379 \pm 76$ & $25.56 \pm 7.06$ & $21.13 \pm 21.83$ \\
\hline & PRF & $110,646 \pm 14,269$ & $724 \pm 97$ & $33.42 \pm 13.06$ & $46.12 \pm 8.60$ \\
\hline JAS standard & & Min 75,000 & Min 300 & Min 54 & Min 54 \\
\hline
\end{tabular}

was $724 \mathrm{kgf} / \mathrm{cm}^{2}$ or much higher than larix glulam.

Based on the analysis of variance presented in Table 4, MOR values were significantly different based on the species of wood, the type adhesive, and their interactions. Based on Duncan's test (Table 5), sengon and jabon were not significantly different.

Shear strength tests were carried out under dry and wet conditions. Table 7 shows that glulam (29.49 \pm $11.07 \%$ ) had lower shear strength values than solid wood (54.45 $\pm 10.61 \%)$. All glulams failed to meet the JAS standard of more than $54 \mathrm{kgf} / \mathrm{cm}^{2}$ for shear strength. Compared to larch cross-laminated timber with resorcinol adhesive reaching shear strength $39 \mathrm{kgf} / \mathrm{cm}^{2}$ (Song and Hong, 2016), the shear strength of jabon glulam using TRF was $32 \mathrm{kgf} / \mathrm{cm}^{2}$ or a little bit lower of larch CLT, but if using PRF the shear strength was $41 \mathrm{kgf} / \mathrm{cm}^{2}$ or much higher than larch CLT.
According to an analysis of variance (Table 6), the species of wood and the type of adhesive affected the shear strength of glulam. Based on the results of Duncan's test (Table 6), TRF adhesive was associated with lower shear strength values compared with those associated with PRF and solid wood. Under dry conditions, sengon and jabon were significantly different, but jabon and mangium were not. Under wet conditions, sengon and jabon were not significantly different from each other, but both were significantly different from mangium. This outcome was due to some mangium sample bonds having failed at the glue line.

\subsection{Cold- and hot-water delamination of glulam}

The results of cold-water delamination (Table 8) indicate that mangium glulam bonded by tannin had 
Table 8. Glulam delamination test

\begin{tabular}{llcc}
\hline \multirow{2}{*}{ Wood species } & Adhesive & \multicolumn{2}{c}{ Delamination } \\
\cline { 3 - 4 } & & Cold water (\%) & Hot water (\%) \\
\hline \hline Sengon & TRF & $2.00 \pm 4.47$ & $1.20 \pm 2.68$ \\
& PRF & $0.00 \pm 0.00$ & $0.00 \pm 0.00$ \\
\hline Jabon & TRF & $0.00 \pm 0.00$ & $0.00 \pm 0.00$ \\
& PRF & $0.00 \pm 0.00$ & $0.00 \pm 0.00$ \\
\hline Mangium & TRF & $23.80 \pm 23.24$ & $67.80 \pm 36.52$ \\
& PRF & $0.80 \pm 0.83$ & $2.80 \pm 2.28$ \\
\hline JAS Standard & & Max 5 & Max 10 \\
\hline
\end{tabular}

the highest ratio of delamination (23.80\%). This result was likely due to mangium having a high density, which prevented the adhesive penetrating deeply into the wood before the curing process. Based on JAS 234 (2003), only sengon and jabon glulams bonded with TRF adhesive met the Japanese standard of less than $5 \%$ delamination. The delamination of both species had a good performance as glulam made from Japanese larch, Korean pine, and Japanese cedar using melamine urea formaldehyde adhesive with delamination values less than $5 \%$ as mentioned by Hong et al. (2017).

In the hot-water delamination test, glulam made from mangium presented delamination, but the extent of it depended on the adhesive used. Mangium glulam bonded with TRF adhesive had the highest delamination value (67.80\%), but mangium bonded by PRF met the JAS 234 (2003) requirement of less than 10\% delamination. As in the cold-water test, sengon, jabon, and mangium-PRF glulam fulfilled the JAS standard for both cold-water (maximum $5 \%$ ) and hot-water conditions (maximum $10 \%$ ). According to the analysis of variance (Table 4), the outcome of delamination tests was affected by wood species, type of adhesive, and their interactions. Duncan's test (Table 5) showed the same results for the delamination tests in hot and cold water; sengon and jabon were not different from each other, but both were different from mangium.
Table 9. Formaldehyde emissions from glulam

\begin{tabular}{lcl}
\hline $\begin{array}{l}\text { Wood } \\
\text { species }\end{array}$ & $\begin{array}{c}\text { Formaldehyde } \\
\text { emissions }(\mathrm{mg} / \mathrm{L})\end{array}$ & Grade* \\
\hline \hline Jabon & 0.05 & $\mathrm{~F}^{* * * *}$ \\
Sengon & 0.04 & $\mathrm{~F}^{* * * *}$ \\
Mangium & 0.04 & $\mathrm{~F}^{* * * *}$ \\
\hline
\end{tabular}

* Categorized by standard JAS 234 (2003)

\subsection{Formaldehyde emissions of glulam}

Table 9 shows that the formaldehyde emissions of sengon, jabon, and mangium glulams can be classified as $\mathrm{F}^{* * * *}$, which is the lowest level of emission and the best class according to JAS 234 (2003). Tannin from bark extracts is rich in phenolic compounds, and thus it may be able to absorb free formaldehyde and at the same time provide strength to the bond (Hoong et al., 2012). The formaldehyde emission of this research reached 0.04 to $0.05 \mathrm{mg} / \mathrm{L}$ and these values were lower than wood-based composite panels with different surface lamination materials, which reached 0.525 to 1.148 mg/L (Park et al., 2016).

\section{CONCLUSION}

1. The condensed tannin extract from mangium bark was $49.08 \%$ phenolic compounds and had a molecular weight of 4745 . The degree of 
Properties of Glued Laminated Timber Made from Fast-growing Species with Mangium Tannin and Phenol Resorcinol Formaldehyde Adhesives

crystallinity was $14.8 \%$, and the Stiasny number was $47.22 \%$.

2. The density and moisture content of the glulams differed from those of the solid wood. Mangium had the lowest moisture content (9.58\%) and the highest density $\left(0.66 \mathrm{~g} / \mathrm{cm}^{3}\right)$.

3. The MOE of the glulam made with TRF adhesive was not different from those of solid wood and PRF glulam, although none of the glulams fulfilled the JAS 234 (2003) standard. Tannin glulam had lower MOR and shear strength than solid wood and PRF glulam. The MOR of all glulams met the standard, but the glulams did not met the standard for shear strength in all conditions.

4. Mangium glulam with tannin adhesive had the highest delamination (67.80\%).

5. All glulams had low formaldehyde emissions. Sengon, jabon, and mangium glulams were classified as $\mathrm{F}^{* * * *}$ for formaldehyde emissions according to JAS 234 (2003).

6. In future work, the purity of tannin should be increased to improve the reactivity of the phenolic compounds with formaldehyde. Greater reactivity could increase the shear strength value of the glulam.

\section{ACKNOWLEDGMENT}

This research was supported by the Ministry of Research, Technology and Higher Education, Republic of Indonesia through Fast Track Doctor (Program Pendidikan Magister menuju Doktor untuk Sarjana Unggul, PMDSU).

\section{REFERENCES}

Achmadi, S.S. 1990. Wood Chemistry. Life Sciences Center, Bogor Agricultural University, Bogor, Indonesia.
Fradinho, D.M., Neto, C.P., Evtuguin, D., Jorge, F.C., Irle, M.A., Gil, M.H., Pedrosa de Jesus, J. 2002. Chemical characterization of bark and of alkaline bark extracts from maritime pine grown in Portugal. Industrial Crops Production 16(1): 23-32.

Hadi, Y.S., Rahayu, I.S., Danu, S. 2015. Termite resistance of jabon wood impregnated with methyl methacrylate. Journal of Tropical Forest Science 27(1): 25-29.

Hendrik, J., Hadi, Y.S., Massijaya, M.Y., Santoso, A. 2016. Properties of laminated panels made from fast-growing species glued with mangium tannin adhesive. BioResources 11(3): 5949-5960.

Hermes, E. 2018. Unpack growth from global trade and e-commerce [internet]. [accessed June 28, 2018]. Available: http://www.eulerhermes.com/ economic-research/sector-risks/Global-Paper-Repo rt/Pages/default.aspx

Hong, M.K., Park, B.D., Kim, K.H., Shim, K. 2017. Performance of Melamine-Urea-Formaldehyde Resin Adhesives at Various Melamine Contents for Bonding Glued Laminated Timber Under High Frequency Heating. Journal of the Korean Wood Science and Technology 45(4): 409-418.

Hoong, Y.B., Paridah, M.T., Loh, Y.F., Jalaluddin, H., Chuah, L.A. 2011. A new source of natural adhesive: Acacia mangium bark extracts co-polymerized with phenol-formaldehyde (PF) for bonding Mempisang (Annonaceae spp.) veneers. Journal International Adhesion and Adhesive 31(3): 164-167.

Hoong, Y.B., Paridah, M.T., Loh, Y.F., Koh, M.P., Luqman, C.A., Zaidon, A. 2012. Acacia mangium Tannin as Formaldehyde Scavenger for Low Molecular Weight Phenol-Formaldehyde Resin in Bonding Tropical Wood. Journal of Adhesion Science and Technology 24(8-10): 1653-1664.

Japan Agricultural Standard. 2003. Glued laminated timber. JAS 234. Ministry of Agriculture, Forestry, and Fisheries, Tokyo, Japan. 
Lee, I.H., Hong, S.I. 2016. Bending and Bonding Strength Performances of Larix Block-glued Glulam. Journal of the Korean Wood Science and Technology 44(3): 315-322.

Lestari, A.S.R.D., Hadi, Y.S., Hermawan, D., Santoso, A. 2015. Glulam properties of fast-growing species using mahogany tannin adhesive. Bioresources 10(4): 7419-7433.

Lestari, A.S.R.D., Hadi, Y.S., Hermawan, D., Santoso, A. 2018. Physical and mechanical properties of glued laminated lumber of pine (Pinus merkusii) and jabon (Anthocephalus cadamba). Journal of the Korean Wood Science and Technology 46(2): 143148.

Panamgama, L.A. 2007. Polyphenolic extracts of Pinus radiata bark and networking mechanisms of additive-accelerated polycondensates. Journal Applied Polymer Science 103: 2487-2493.

Park, B.D., Kang, E.C., Lee, S.M., Park, J.Y. 2016. Formaldehyde Emission of Wood-Based Composite Panels with Different Surface Lamination Materials Using Desiccator Method. Journal of the Korean Wood Science and Technology 44(4): 600-606.

Pizzi, A. 1983. Tannin-based wood adhesive. In: Wood Adhesive: Chemistry and Technology. M. Dekker,
New York, NY, pp. 177-246.

Santoso, A., Hadi, Y.S., Pizzi, A., Lagel, M.C. 2016. Characterization of merbau wood extract used as an adhesive in glued laminated lumber. Forest Products Journal 66(5/6): 313-318.

Song, Y.J., Hong, S.I. 2016. Evaluation of Bonding Strength of Larch Cross-Laminated Timber. Journal of the Korean Wood Science and Technology 44(4): 607-615.

Valenzuela, J., Von Leyser, E.P., Pizzi, A., Westermeyer, C., Gorinni, B. 2012. Industrial production of pine tannin-bonded particleboard and MDF. European Journal Wood \& Wood Production 70(5): 735-740.

Vazquez, G., Freire, S., Gonzalez, J., Antorrena, G. 2000. Characterization of Pinus pinaster bark and alkaline extracts by diffuse reflectance Fourier transform infrared (DRIFT) spectroscopy. Holz als Roh- und Werkstoff 58(1/2): 57-61.

Von Leyser, E.P., Pizzi, A. 1990. The formulation and commercialization of glulam pine tannin adhesives in Chile. Holz als Roh- und Werkstoff 48(1): 25-29.

Yazaki, Y., Collins, P.J. 1997. Uses of wattle extract: Tannin based adhesive. Rural Industries Research and Development Corporation RIRDC Publication 97/72, Chapter 15, pp. 127-143. 